\title{
Resilience as transformative capacity: exploring the quadripartite cycle of structuration in a Mozambican resettlement programme
}

Article

Accepted Version

Arnall, A. (2015) Resilience as transformative capacity:

exploring the quadripartite cycle of structuration in a

Mozambican resettlement programme. Geoforum, 66. pp. 2636. ISSN 0016-7185 doi:

https://doi.org/10.1016/j.geoforum.2015.08.015 Available at https://centaur.reading.ac.uk/41866/

It is advisable to refer to the publisher's version if you intend to cite from the work. See Guidance on citing.

To link to this article DOI: http://dx.doi.org/10.1016/j.geoforum.2015.08.015

Publisher: Elsevier

All outputs in CentAUR are protected by Intellectual Property Rights law, including copyright law. Copyright and IPR is retained by the creators or other copyright holders. Terms and conditions for use of this material are defined in the End User Agreement. 


\section{CentAUR}

Central Archive at the University of Reading

Reading's research outputs online 


\title{
Resilience as transformative capacity: exploring the quadripartite cycle of structuration in a Mozambican resettlement programme
}

\begin{abstract}
The concept of resilience has emerged out of a complex literature that has sought to make sense of an increasingly interconnected world that appears ever more beset by crises. Resilience's appeal is reflected by the burgeoning mass of literature that has appeared on the subject in the past five years. However, there is ongoing debate surrounding its usage, with some commentators claiming that the term is inherently too conservative a one to be usefully applied to situations of vulnerability in which more radical social change is required. This article extends existing efforts to formulate more transformative notions of resilience by reframing it as a double-edged outcome of the prereflective and critical ways in which actors draw upon their internal structures following the occurrence of a negative event, thus reproducing or changing the external structural context that gave rise to the event in the first place. By employing a structuration-inspired analysis to the study of small-scale farmer responses to a flood-induced resettlement programme in central Mozambique, the article presents a systematic approach to the examination of resilience in light of this reframing. The case study findings suggest that more attention should be paid to the facilitative, as well as constraining, nature of structures if vulnerable populations are to be assisted in their efforts to exert transformative capacity over the wider conditions that give rise to their difficulties.
\end{abstract}

\section{Introduction}

There is urgent need to assist poor and impoverished people in the face of ongoing global crises, such as climate change (IPCC, 2014). The idea of building resilience as a means to enable people to cope with the impacts of external shocks and stresses has gained considerable currency of late (Bene et al., 2012). However, there is ongoing debate over what resilience is and what role it should play in interventions designed to increase the welfare of the poorest people in society. Traditional interpretations of resilience can emphasise maintenance of the status quo, thus making the concept appear a relatively conservative one. However, as models of resilience have increasingly been applied to the analysis of social systems around the world, there is growing awareness of the need to develop more dynamic versions of the concept that include possibilities of adaptation and transformation (Pelling and Manuel-Navarrete, 2011). 
This article extends existing efforts to understand resilience as more than ability to return to preexisting conditions by presenting empirical evidence from central Mozambique to illustrate ways in which individuals and groups act to alter patterns of resource distribution in their favour, thus changing the status quo to lessen the impacts of negative events in the future. Using the concept of the 'quadripartite cycle of structuration' (Giddens, 1984; Stones, 2005), it reframes resiliency as a double-edged outcome of the pre-reflective and critical ways in which actors draw upon their internal structures following the occurrence of a negative event, thus reproducing or changing the external structural conditions which gave rise to the event in the first place. This perspective calls into question the dominant idea in resilience theory that agency and structure are discrete entities, with structures acting in direct opposition to actor intentions. It provides those seeking to enhance the resilience of vulnerable groups with greater analytical intelligibility in identifying opportunities for social transformation, even under conditions in which vulnerable people have been subjected to conditions of prolonged stress.

The first half of this article is an extended literature review that accomplishes three goals. First, it reviews the capabilities and limitations of existing resilience-based approaches in development. Second, noting the need for a more politically-oriented reframing of the resilience concept, it introduces Rob Stones' (2005) quadripartite cycle of structuration. Third, it integrates key elements of resilience theory into this cycle so as to place the dynamic interplay of agency and structure at the centre of analysis. In the second half of the article, the resulting framework is applied to a case study of small-scale farming villages in Caia District, central Mozambique. The villages were created in 2007 when large-scale flooding caused the Mozambican government to permanently resettle tens of thousands of households from the Lower Zambezi River valley to nearby areas of higher land. Resettlement, in this case, is intended by government and donors to enhance the resilience of farmers by removing the threat of floods to their houses and crops. However, as this article shows, resettlement is itself a disruptive event that produces a range of livelihood and resiliency outcomes for different groups of people. The analysis focusses on one group of disadvantaged small-scale farmers in particular, the so-called 'returnees' or repatriados, who experienced land dispossession in the early 1990s. Following relocation to the high area, some repatriados were able to draw on their internal structures in novel, critically reflective ways whilst adjusting themselves to their new surroundings, thus intervening in, and challenging, internalised patterns of external meaning, behaviour and resource distribution. This allowed them to alter their social and physical environments so as to effectively mitigate the impacts of future floods on their agricultural activities. The findings suggest that greater attention needs to be paid to the facilitative nature of social 
structures in resilience building programmes, and how the priorities of governments and development organisations can be more effectively aligned with the ongoing negotiations and strategies of people affected by shocks and stresses.

\section{Towards a structuration-based approach to resilience}

\subsection{Resilience and development}

Despite much debate amongst researchers concerning its conceptualisation, usage of the term 'resilience' often falls into one of two camps. The first camp is grounded in ecological science, and focuses on the maintenance of the structure and function of socioecological systems in the face of shocks and stresses (Folke, 2006). The second camp, which informs the understanding of resilience taken in this article, relates to the medical sciences which, since the 1960s, have sought to understand individuals' capacities for positive adaption in the face of disturbance and trauma (Bottrell, 2009). In recent years, the focus on the individual has been scaled up to the group level, where households, organisations and communities are viewed as coordinated bodies capable of responding to a range of crises (Norris et al., 2008). In particular, there has occurred a proliferation of models in the past ten years to define the characteristics of disaster-resilient communities (IISD, 2003; Twigg, 2007) or measure community-based resilience (Ainuddin and Routray, 2012; Cutter et al., 2008).

There is little doubt that the resilience concept offers a compelling source of theoretical insight, and provides new sets of tools with which to analyse the situations of people living in conditions of adversity (Popkea et al., 2014). However, as the concept's popularity has grown, it has become increasingly subject to criticism in two main ways. First, resilience is often unquestioningly associated with wellbeing or 'goodness', thus creating an assumption that resilience is an end in itself (Bene et al., 2014). However, as pointed out by Coulthard (2012), resilience is a neutral characteristic which, by itself, is neither good nor bad, and some households that strengthen their resilience can do so at the expense of their overall wellbeing.

Second, the concept says little about the role of power in determining development outcomes for people (Cannon and Muller-Mahn, 2010; Davidson, 2010; Davoudi, 2012; Walker and Cooper, 2011). As a result, individuals and groups risk being viewed as resilient to the extent they adapt to, rather than alter or transform, 'the conditions of their suffering' (Welsh, 2013;16). The concern is that, without a more radical conceptualisation of resilience, the more apolitical version - with its 
emphasis on individuality and self-reliance - is easily malleable to fit a variety of dominating ideologies (Hulme, 2007).

These criticisms highlight the need for a more dynamic and politically-oriented reframing of the resilience concept, one that includes demonstration of not just how adaptations to external shocks and stresses might occur in the presence of wider structural forces, but also how those structures themselves might come to be challenged as part of this process. While there are many possible ways to achieve this reframing, this article argues that seeing resilience as an outcome of the ways in which people work both with and against structures in their day-to-day social interactions points towards a reframing of resilience around the theory of structuration.

\subsection{Structuration theory}

The theory of structuration was introduced by Anthony Giddens in his book, The Constitution of Society (1984). Structuration aims to resolve a long running debate in the social sciences, that of whether human action is primarily driven by agency, including individual needs, desires and wants, or whether it is mostly determined by wider societal structures, such as norms and constraints, which interact with individual action (Cleaver, 1999). Giddens' central argument was that structures are not phenomena that are simply 'out there', shaping people's needs and desires, but are socially constructed through the actions of individuals and groups in a continual process of renewal or alteration as they go about their daily activities. Structure therefore frames, and is also the product of, agency and the interaction of these two qualities produces the social system under examination.

Giddens captured these ideas in the concept of 'duality of structure', by which he meant that structures are both the means and outcomes of social action (Giddens, 1979;5). Giddens argued that structure enters into the make-up of agents, and from here into the practices that the agent produces. Thus, when agents interrelate, they draw on their structural properties to help them formulate their positions and achieve their objectives. However, in doing so, they also reproduce or change the structural context that allowed them to act in the first place, thus setting up the preconditions for the next phase of activity. These ideas are significant because they challenge the prominent idea that the 'structural properties of society form constraining influences over action', introducing the notion that structure is both 'enabling and constraining' of human action (Giddens, $1984 ; 169)$. 
Giddens' work also challenges the view that power is primarily a domineering, sometimes pernicious, force that shapes socioeconomic and political development outcomes for different groups of people (Wilson, 2006). It suggests that power is not only oppressive, but can also be productive, in that it facilitates social actors to form their interests and pursue their goals. This is because underlying the agency-structure nexus is 'the rationalisation of action against the background of the agents' reflexive monitoring of their conduct' (Giddens, 1984;3). In other words, "actors routinely...maintain a continuing 'theoretical understanding' of the grounds of their activity", one which accounts for most of what they do (Giddens, 1984;5). Using this understanding, actors continuously monitor their actions and the actions of those around them, not only to follow their day-to-day routines, but also to adjust their behaviours to attempt to turn structural properties to their advantages. Power, then, is the 'transformative capacity' to intervene in, and affect, the regularised flows of social interaction by going through the above reflexive process (Giddens, 1984;91).

Structuration theory has been used extensively in the social sciences, being applied to topics as diverse as strategic corporate management (Pozzebon, 2004), mammal hunting in Africa (Campbell, 2005) and humanitarian aid interventions (Rodon et al., 2012). However, structuration has also been criticised by social theorists who have questioned Giddens' notion that structures exist 'only in a virtual way, as memory traces and as the instantiation of rules in the situated activities of agents' (Giddens, 1989;256), arguing that it downplays the fact that structures can also 'exist in a social and material context, and as interactions between persons' (Hodgson, 2007;104). In recent years, the sociologist Rob Stones (2005) has endeavoured to address these criticisms by proposing a 'quadripartite cycle of structuration' (p.9). In this cycle, Stones identifies four critical elements of structuration theory:

1. External structures, which form the structural context that the agent faces at the start of the cycle, and which constitute the preconditions for action;

2. Internal structures within the agent, which can themselves can be divided into two parts: 'conjunctionally-specific' or 'positional' structures, which are directed towards external structures, and involve an agent's knowledge of the specific context of action, and 'habitus', which makes up the part of social life that is normally taken for granted and left unquestioned;

3. Active agency or the agent's practices, which represent the ways in which actors either prereflectively or critically draw on their internal structures; and 
4. Outcomes, which can involve change and elaboration or reproduction and preservation of the structural context, and which can serve to facilitate or frustrate the objectives of the agent.

The strength of Stones' model is that it explains the role of structures which form the means and outcomes of social action, whilst also clarifying where such structures exist when agents interact. With this in mind, the next section outlines how agency and structure have been dealt with in the resilience literature to date, before introducing the framework that will form the basis of the empirical analysis.

\subsection{Resilience and structuration}

To date, the resilience literature has engaged with the concepts of both agency and structure, although the former has been the main focus of this body of work. Agency has been understood as the ability of actors to mobilise economic, technological and informational resources in the face of shocks and stresses (Norris et al., 2008), often via social processes such as reciprocity and interpersonal trust (Patterson et al., 2010), or good leadership and individual support for collective action (Schwarz et al., 2011). The approach to agency taken in this article builds upon Giddens' notion of the 'rationalisation of action' or actors' understandings of the bases of their actions. Although there are potentially many different dimensions to these understandings, they are interpreted here as the procedures whereby different actors' projects in similar or separate spheres of life are prioritised, ordered and integrated together (Archer, 2000; Craib, 1997). According to Stones $(2005 ; 21)$, this means that 'when an agent engaged in a particular action draws on structures...she must keep in mind her other projects, their likely contexts, and what is likely to be required to fulfil them'. This is not to imply, however, that such a process will always be coherent and rational: as Stones (2005) states, rather than 'integration' implying harmony, there might be tensions and contradictions between priorities of which actors are more or less aware of depending upon their particular positions, viewpoints, affiliations and connections at the time. Such processes are relevant to resilience research because they allow analysis of how an actors' priorities might change following the occurrence of a negative event.

More recently, the focus on human agency in resilience research has been complemented by growing awareness of the role of social structure. 'Structures' can take various forms, but have mostly been understood as political-economic conditions (Fieldman, 2011), ways of understanding both cognitive (Grothmann and Patt, 2005) and cultural (Kuruppu, 2009; Nielsen and Reenberg, 2010) - and institutions (Lebel et al., 2011). Giddens (1984) himself identified three types of 
structure: 'signification', constituted by the interpretations and meanings assigned to social phenomena, 'legitimation', consisting of norms and rules, and 'domination', made of up patterns of resource distribution, within which are included both control of economic, or allocative, resources and control over people or authoritative resources. As their name suggests, structures of domination can be oppressive, constituting, as they do, asymmetrical access to resources. On the other hand, the concern with agency taken in structuration theory means that structures of domination can also be contested and changed, even under the most difficult of circumstances (Crawford and Andreassen, 2013).

Traditionally, agency and structure have been treated as separate entities within resilience theory, with structures viewed as externally-generated and acting in opposition to human agency. The framework utilised in this article takes a different starting point. It begins with the quadripartite cycle of structuration and, within this model, considers agents' responses to recover from, or mitigate against, a negative event (Figure 1).

Figure 1: The quadripartite cycle of structuration and resilience to a negative event

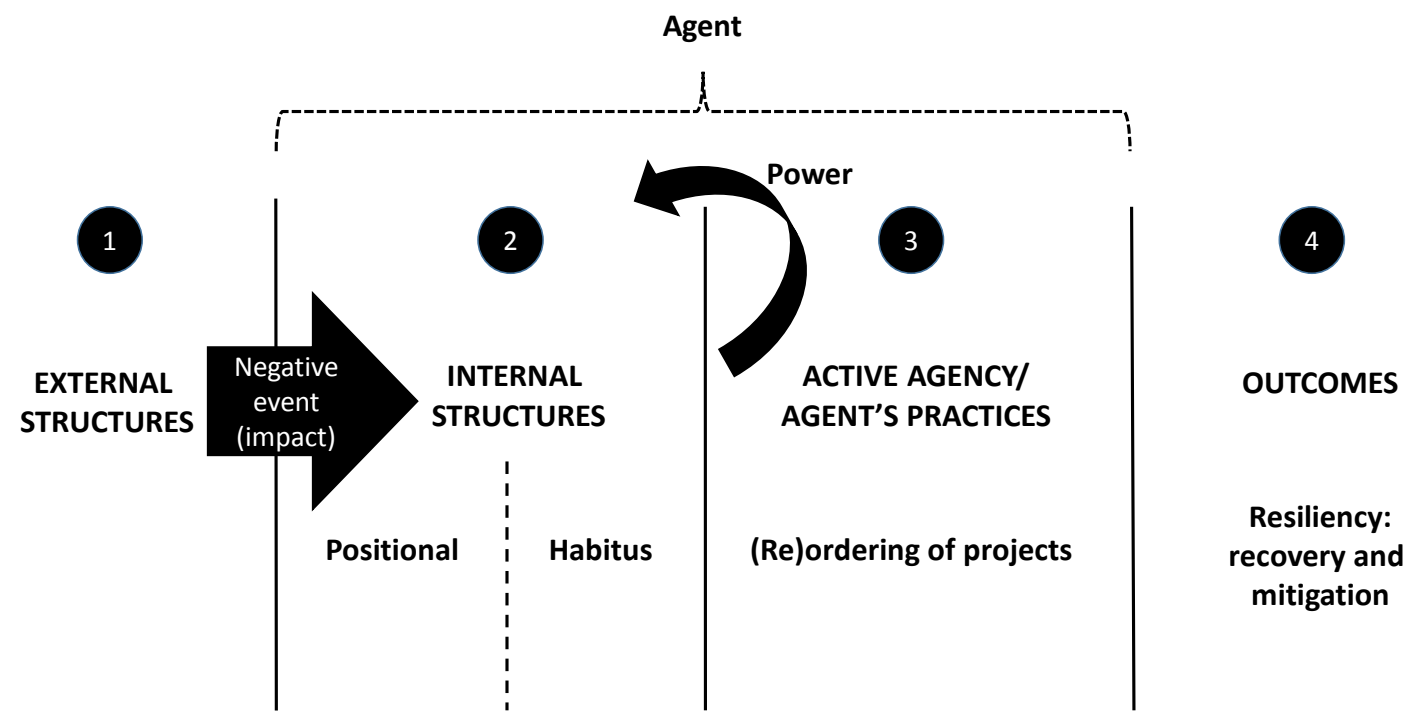

Adapted from Stones $(2005 ; 85)$

In Figure 1, the negative event, or impact, which instigates the response, is shown as emerging out of the external structures (step 1), or preconditions for action, themselves. In this sense, the production of negative events is viewed in a similar manner to the 'pressure and release' model developed by Wisner et al. (2003). According to this model, natural disasters are phenomena which 
emerge out of the wider structural conditions of inequality and vulnerability within which actors are situated, rather than simply being caused by the occurrence of the negative event in the first place. Similarly, the 'external structures' idea in the cycle of structuration takes into account both the physical event (such as a flood or landslide) and the social circumstances which transform the event into a disaster. These phenomena are 'outside' the agent only in the sense that they have an existence that is autonomous from the agent-in-focus, and would still occur in the world regardless of whether the particular agent under consideration existed or not.

A negative event can affect an agent in two main ways. First, it can impact upon the agent's internal structures (step 2), especially those that are conjuncturely-specific or positional, as people's contexts-for-action are jolted and habitus potentially challenged. Second, it can stall agents' progress towards fulfilment of their ordered concerns that existed in the pre-event environment, causing them to reprioritise their projects (step 3). In doing so, some actors might draw on their internal structures in new, critically reflective ways, intervening in, and challenging, accepted patterns of meaning, behaviour and resource distribution. This process of internal intervention is symbolised in Figure 1 by the 'power' arrow.

Two main outcomes (step 4) will result from the occurrence of the negative event. The first outcome relates to the resiliency of the agent, which is understood in terms of its recovery from, or mitigation of, that event (Brown and Kulig, 1996). Recovery signifies that agents have returned to a 'normal' state, in the sense that they are able to continue working towards the same project priorities that they had before the negative event occurred. Mitigation, however, implies that agents have altered their physical and/or social environments to protect against the reoccurrence of similar negative events in the future. This will normally involve a permanent alteration of the agent's project priorities. Secondly, the effect of these processes will be reproduction and preservation or change and elaboration of the existing structural context from which the impact originally emerged.

Figure 1 essentially operates as a cycle, the outcomes in step 4 forming the conditions for the next phase of action. In Figure 2, the connection between step 3, active agency, and step 4 of the cycle is elaborated. The Figure shows that actors pre-reflectively or critically, and individually or collectively, draw on their internal structures following the occurrence of a negative event, and that these processes lead to four strategic orientations which promote recovery from, and/or mitigation of, that event: coping, coordinating, confounding and converting. On the left-hand side of Figure 2, actors behave in ways that largely reflect existing structural constraints; they exert little power as a 
consequence, and the structural conditions which led to the emergence of the stress or shock in the first place are reproduced. In contrast, actors on the right-hand side behave by exercising power as symbolised by the arrow shown in Figure 1. It is in this latter zone of Figure 2 where resilience as transformative capacity is located.

Figure 2: Actors' strategic orientations following the occurrence of a negative event

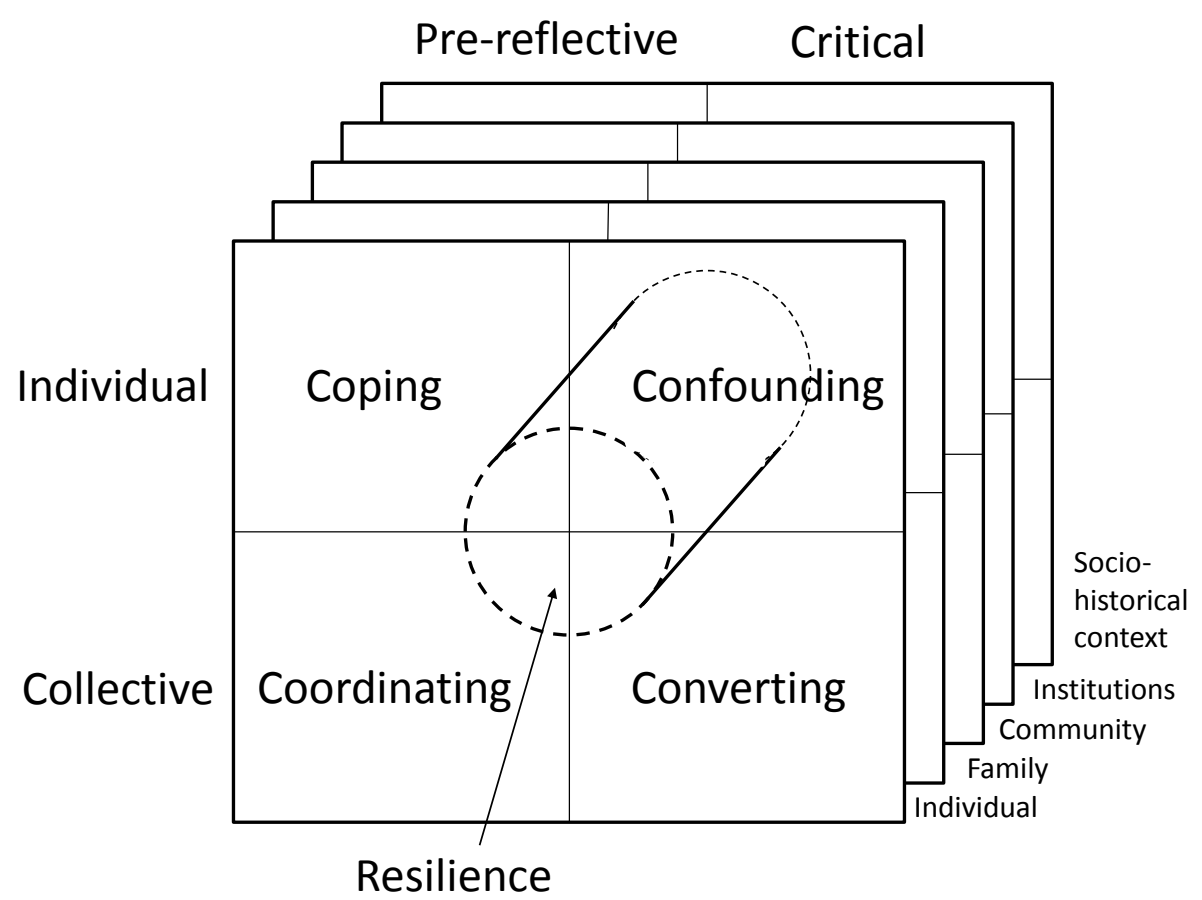

According to Lister (2004), different combinations of agency may be exerted over time, in different circumstances, and in relation to different types of hazard. For this reason, it can be expected that a resilient entity is capable of exerting all of the strategic orientations shown in Figure 2, and this is reflected by the positioning of the resilience 'space' in the middle of the matrix. Figure 2 also accounts for the possibility of being resilient at multiple scales, such as families or communities acting individual and collectively, as well as within the wider institutional and socio-historical contexts in which they are positioned. This reflects Schoon's (2006) resilience model which incorporates numerous and interconnected spheres of influence.

The focus taken in this present article is on the intermediate community level, although the other 'levels' also play a role and are explored as appropriate. According to Agrawal and Gibson (1999), there are many ways to define what a community is. From the perspective of structuration theory, a community can be viewed as a group of people in a similar context sharing a common set of ordered concerns, priorities or projects in the pre-impact environment. However, this definition is not 
intended to imply that, post-impact, a community will necessarily be able to act harmoniously towards a common goal. Rather, it is necessary to consider factors such as patterns of difference, the existence of subgroups, and multiple, and sometimes conflicting, interests within communities that will affect its behaviour to operate in a coordinated fashion (Mansuri and Rao, 2004).

In summary, following the occurrence of a negative event, structures form both the means and ends of actors' attempts to make sense of their new, post-impact environments. Central to this process is the ways in which a negative event arises and impacts upon actors' internal structures, as well as the strategic orientations and resiliency outcomes that emerge as a result. The next section considers what these processes mean in the context of a resettlement programme in the Lower Zambezi River valley region in central Mozambique.

\section{Setting the context: flooding and small-scale farming in the}

\section{Lower Zambezi River valley}

\subsection{Livelihoods, land and repatriados}

The Lower Zambezi River extends over $700 \mathrm{~km}$ across central Mozambique, from the Cahora Bassa dam located in Tete Province to the Indian Ocean. The river valley region, which sustains the livelihoods of some 2.8 million small-scale farmers (Scodanibbio and Manez, 2005), is associated with two main agro-ecological areas: a low area (zona baixa) close to the river and an elevated high area (zona alta) a few kilometres away (FEWS NET, 2011).

Across these two zones, patterns of settlement and crop production are complex, with small-scale farmers living in either the high or low areas, and growing crops in one zone or the other, and sometimes across both. Landownership is a major determining factor of where farmers live and work in three main ways. First, the greater the area a small-scale farmer can cultivate, the greater their financial return will generally be (Jayne et al., 2003). In more densely settled areas where population growth has created constraints to landownership, as in the Lower Zambezi River region, rural poverty has become closely associated with inadequate access to land (Jayne et al., 2010).

Second, small-scale farmers operating in Mozambique face multiple sources of risk, including irregular and unpredictable rainfall, outbreaks of animal diseases, livestock theft, and damage to crops caused by animals (USAID, 2008). Farmers in the Lower Zambezi River valley region respond to these hazards via a risk management system centred on multiple plots of land spread over relatively 
large areas and elevations (lanni, 2012). In this way, the impacts of any single plot failing to produce in a particular year are minimised due to varying soil and microclimatic conditions.

Third, land tenure is a major consideration for small-scale farmers. In Mozambique, customary rights over land are formally recognised - either through inheritance or extended use - and this system accounts for around 90 percent of land rights nationally (Boyd et al., 2000). However, in areas of land constraint, other forms of ownership and access might arise. The most secure of these is 'formal allocation', whereby a plot of land is apportioned to an individual on a permanent basis by the local authorities. Other, less secure forms include 'renting' and 'borrowing', in which farmers access relatively small agricultural plots in return for which they must provide the plot owner with a proportion of the profit that they derive from that land use.

These three factors - land area, location and tenure - play a major role in determining farmers' socioeconomic status in rural Mozambique. In the Lower Zambezi River valley region, better off farmers tend to have more land in favourable locations in the high and low areas, and have more secure tenure over that land. They also possess more livestock, such as goats and cattle. As a result, typical annual household incomes of better off families can be up to six times higher than those of the poorest, reflecting high levels of regional rural inequality (Jayne et al., 2010).

One of the worst off groups in the Lower Zambezi River valley region are 'returnees' or repatriados (West and Myers, 1996). These are small-scale farmers who originally lived in the high area but moved to the low area in the early 1980s in an attempt to avoid the conflict of the civil war. Following the cessation of hostilities in the early 1990s, many repatriados attempted to return to their former homesteads in the high area. However, repatriados found that their former lands had become occupied by other groups of farmers returning to rural areas from urban centres. Today, due of this historical legacy of dispossession, repatriados normally occupy the smallest areas of land in the low area only (Oliveira, 2010). It is on the basis of this shared history, as well as the repatriado emphasis on low area based agriculture, that this group of small-scale farmers forms the community-in-focus in this article's empirical analysis.

\subsection{Flooding, resettlement and resilience-building}

Farmers in possession of houses and fields in the low area are vulnerable to flooding which occurs annually during the second half of the rainy season (December to March). In recent years, a succession of weather extremes has increased the frequency and severity of flooding events (Ribeiro 
and Dolores, 2011). Particularly major inundations in 2007 led the government to permanently resettle tens of thousands of small-scale farmers, including repatriados, from the low area to new high area settlements a few kilometres away. These activities were accompanied by interventions led by nongovernmental organisations (NGOs) designed to consolidate people's livelihoods in their new surroundings (Chambote and Boaventura, 2008). At the same time, the government began to withdraw services, such as schools and health centres, from the low area in the hope that it would dissuade people from returning to the river valley to live.

In recent years, the possibility of resettlement acting as a resilience building measure to climaterelated shocks and stresses has been considered by national governments (McDowell, 2013). This is because relocation can remove entirely the direct effect of hazards, such as floods or landslides, on homes and assets (Correa, 2011). In Mozambique, resettlement out of floodplains to surrounding areas of higher land has similarly been viewed by government as a key intervention to build resilience (Arnall, 2014). Relocated people are no longer at risk of direct exposure to floods. In addition, they are, in theory, able to continue farming in the low area with the possibility of exploiting new agricultural opportunities in the high area. For example, in 2011 the UK Department for International Development (DFID) used the case of resettlement in central Mozambique to illustrate how it has been 'increasing resilience to climate change' by 'strengthening and diversifying the livelihoods' of relocated people (DFID, 2011).

In spite of a few examples of success (cf. Petz, 2015), the general suitability of resettlement as a resilience building measure is contentious due to its socially disruptive nature (Gebauer and Doevenspeck, 2014). In the Mozambican context, two challenges stand out in particular. The first challenge concerns land governance. Traditionally, local chiefs, called regulos, oversee kin-based systems of land acquisition and inheritance, and resolve land-related disputes within communities (West and Kloeck-Jenson, 1999). However, debate continues over the extent to which local leaders truly represent local interests, with scholars arguing that, in some cases, local chiefs have used their positions for personal gain (Kyed and Buur, 2006; Toulmin, 2008). As part of the resettlement programme in the Lower Zambezi River valley region, district authorities negotiated with high areabased regulos to appropriate 'idle' land from within their domains to allocate to incomers. However, the fairness with which land was subsequently distributed amongst relocated people has been called into question (Artur and Hilhorst, 2014). 
Second, resettled people need to secure viable livelihoods in their new surroundings, otherwise resettlement managers run the risk that relocatees will 'abandon' their new homes (Koenig, 2005). In Mozambique, desertion of resettlement areas in favour of former, low area homesteads is a common outcome of relocation following floods (Patt and Schroter, 2008). Indeed, in the central region of the country, Artur and Hilhorst (2014) estimated that one third of farmers abandoned resettlement villages in the weeks and months following relocation in 2007. Taken together, these two issues raise questions over whether resettlement can meet the needs of all social groups that it purports to be assisting. They help to explain recent growing awareness amongst donors in Mozambique in the concept of 'living with floods', which means accepting large numbers of people living on floodplains and developing mechanisms to minimise risk in-situ (UN HABITAT, 2012).

\subsection{Fieldwork and methods}

The geographical focus of this article is Caia District, Sofala Province. The District lies to the south of the Lower Zambezi River valley and in close proximity to the national north-south N1 road. The majority of its population is situated along the District's main thoroughfare, which runs between the market towns of Caia and Sena. Caia District is widely recognised as of growing interest to international and nationally-based land investors, which has constrained high area land access in the region (Ianni, 2012).

Fieldwork for this article was conducted in four resettlement villages in Caia District between July and September, 2011-2012. The villages were purposively selected on the basis that they were described by key informants in the region as having high numbers of repatriado households. The primary data were collected via 67 semi-structured interviews with village representatives $(n=54)$, NGOs $(n=7)$ and district government $(n=6)$. The distribution of households and interviews across the villages are shown in Table 1.

Table 1: Distribution of households and interviews across resettlement villages

\begin{tabular}{|l|l|l|}
\hline Village $^{\mathbf{1}}$ & $\begin{array}{l}\text { Number of households } \\
\text { (number of repatriado households) }\end{array}$ & $\begin{array}{l}\text { Number of interviewees } \\
\text { (number of repatriado interviewees) }\end{array}$ \\
\hline Inaçia & $98(21)$ & $3(2)$ \\
\hline Maguade & $110(42)$ & $13(8)$ \\
\hline Telenina & $154(30)$ & $18(12)$ \\
\hline Tombara & $160(28)$ & $20(15)$ \\
\hline Total & $522(121)$ & $54(37)$ \\
\hline
\end{tabular}

${ }^{1}$ Village names have been changed to help preserve anonymity of respondents. 
Interviewees were selected using a snowballing sampling strategy, and in consultation with local stakeholders, to ensure that the main institutional divisions in villages, such as gender and social status, were represented, and this process continued until 'saturation point' in the stories being gathered was reached (Bailey et al., 1999). Of the 37 repatriado households interviewed, 15 were headed by 'single' (i.e. unmarried or widowed) women, a demographic identified as economically worse off when compared to households led by a single man or by a husband and wife (CMI, 2010). The interviewed repatriado group also included six households led by so-called 'middle farmers'. These were people whose parents were favoured by the Portuguese authorities in the 1950s in an attempt to create a class of peasants who would produce for the market (van den Berg, 1987).

The research design and methods were subject to the standard ethical review procedures employed by the author's research institution. Discussions during interviews focussed on repatriados' lives before resettlement, their experiences of the resettlement process, and how their living conditions had changed in the high areas. In addition, following procedures outlined in Pratt and Loizos (1992) and by FFI (2013), one Venn diagram, wealth-ranking and timeline exercise was conducted in each village with groups of small-scale farmers. These were undertaken to stimulate discussion about social organisation and differentiation, and the progression of the resettlement programme, in greater depth. Reports produced by district government and NGOs on local problems and development initiatives were also collected and reviewed. In addition, visits to three farms in the low area and attendance at four meetings between NGO fieldworkers and resettled farmers allowed the author to directly observe the challenges that smallholders faced. Observations made during visits and meetings were recorded in a field diary which took the form of a handwritten journal that was updated daily. Keeping a diary aided management of the author's thoughts and emotions during fieldwork, and assisted recall and reflection during data analysis (Punch, 2012). Overall, the mixture of methodological techniques employed ensured that data could be cross-checked at all stages of the research process.

\section{Structure, agency and resilience in Caia District}

\subsection{External and internal structures}

Prior to resettlement in 2007, repatriados' agricultural activities occurred entirely within the low area. In this zone, crop production took place over two seasons: a first season between October and late December, before floodwaters rose, and a second between March and September, when flood recession agriculture was practiced. During interviews, however, members of this community commonly described how their agricultural activities had become increasingly difficult in the early 
2000s as seemingly larger and larger flooding events had taken place. These incidents caused repeated, temporary displacements of families from the river valley, as well as regularly washed away crops, homes, agricultural equipment and food stores. One particularly common problem was the early rising of floodwaters in late November or early December. These incidents caused crops planted at the start of the first growing season to be lost. In addition, especially large floods took longer periods of time to subside than normal, leading to delays in agricultural production during the second growing season.

At the time, repatriados recognised that reclaiming high area land would allow them to plant crops that were out of the reach of floodwaters during the first growing season. Land reclamation involved gaining the approval of the high area regulo in whose domain the land was located whilst submitting a formal request to the nearby district administrator's office. However, it was commonly reported that such claims were unsuccessful. For example, one repatriado called Rosa described how, in 2006, she had spoken with a high area regulo about accessing a 0.5 hectare plot formerly used by her but which was being worked on at the time by an agricultural association for the production of cotton. According to Rosa, the regulo had quickly dismissed her enquiry. As she explained: "The leader looks at you and sees how you live. We don't have much, we are simple people, and so the leader thinks, 'How is this person going to be able to use the land properly. They will just waste it'". Although Rosa was unhappy with the regulo's response she also stated that she had not pursued her claim any further as it was "not her place" to question what leaders said.

This outcome, as well as other similar experiences reported by repatriados, can be explained by reference to the general dispositional frame of this community before resettlement. In Mozambique, structures of signification portray regulos as guardians or protectors of natural resources who represent the people's historic connection to the land upon which they depend (West and Kloeck-Jenson, 1999). Prevailing structures of legitimation mean that it is often not considered appropriate to question what a regulo says or does (West, 1998). Moreover, these codes of conduct are reinforced by localised systems of domination which are grounded in the regulos' positions of relative wealth, education and privilege (Alexander, 1997;11).

Discussions with repatriados suggest that, before resettlement took place, these understandings were overwhelmingly drawn upon 'naturally', in a pre-reflective manner, when this community engaged with local authority figures. Consider, for example, the following extract, taken from an 
interview with João, a repatriado who, previous to 2007, had supported a family of five on a one hectare-sized farm in the low area.

(Q) How did you manage to support your family?

(A) It was very hard. The children could not go to school and there were no things for the house. Sometimes we would lose crops to the floods and then we would go hungry.

(Q) Did you have land in the high area?

(A) No, not then.

(Q) Did you try to regain your land in the high area?

(A) Some did but I never heard of anyone succeeding.

(Q) Why did no one succeed?

(A) I don't know. It's just how things worked. When the regulo [in the high area] spoke then others just listened. They did what he said.

(Q) Did anyone ever question what the regulo said?

(A) Not that I know of. People wanted to live well with the regulo and follow what he said. It was important to show that we could all live together.

This approach to talking about life before resettlement was common during interviews with repatriados. Obedience to local authorities appeared to be naturalised to the extent that it was uncritically associated with 'living well' - and therefore remained within the largely unconscious domain of habitus - in spite of the flooding problems that small-scale farmers based in the low area had repeatedly faced. Moreover, interviews revealed a generally restrictive conjunctural knowledgeability amongst repatriados of the external structures of domination that they faced from their positions in the river valley. For example, prior to 2007, many repatriados had been concerned that appearing uncooperative to local authorities would result in unfavourable treatment during the distribution of humanitarian aid following flooding events. As one NGO fieldworker explained:

"During times of floods, we [the NGO] rely on the community leaders [to help us distribute aid]...The farmers in the low area are aware of this. It means that they are careful not to upset the leaders as the next time there is a flood the farmers might not receive".

Following the implementation of the resettlement programme in 2007, the low area repatriados were relocated to the high area alongside small-scale farmers from other socioeconomic groups. Under the programme, each relocated household was supposed to receive a small house constructed from 'modern' materials such as brick and zinc sheeting, and a small plot of high area land (Stal, 2011). In reality, however, the patterns of resource distribution evident in the wider Lower Zambezi River valley region were initially reproduced in the resettlement villages. Thus, houses and land were distributed by local authorities along existing wealth structures. This meant that many repatriados lost out in relation to other farmers already in possession of larger units of 
land and greater numbers of livestock. Repatriados found themselves living in the high area, in some cases many kilometres from their low area farms, with their crops still exposed to flooding.

This example shows how, once again, the repatriado community was disadvantaged within the external structures of domination in the Lower Zambezi River valley region. However, the 'shock' of the relocation process also caused a 'jolt' to the internal structural constitutions of this community. People relocated to the high area encountered a much wider array of actors and power centres than they had previously experienced, with NGO fieldworkers and local government authorities suddenly involved in the provision of livelihoods support in addition to traditional authority figures. Thus, the regulos' role was diminished as residents of resettlement villages were drawn closer to the formal structures of the state. Moreover, many repatriados had witnessed first-hand the recreation of prevailing structures of domination in the high area settlements, an experience that ran contrary to the government's promise that resources in the high area would be distributed on an equitable basis. As a result, some regulos began to be regarded as 'meddlers' in the resettlement process. This was especially the case with regard to the distribution of housing. As one repatriado explained:

"Before we moved [to the high area] we were told by the government that we would all receive the same house [in the resettlement village]. But when I arrived I had to wait many months to receive the zinc [sheet] for the roof...The leaders got theirs in the first week. It was waiting for them when we arrived".

Thus, resettlement in this case resulted in a situational context that was unfavourable to the maintenance of habitus. As a result, prevailing structures of legitimation began to be called into question by many repatriados. For example, one NGO fieldworker, whilst reflecting on recent tensions between resettled farmers and government district staff in one resettlement village, commented: "When people are resettled, it changes them. They become more demanding and expect more things to be provided". These changing dispositions towards authority amongst relocated farmers were widely reported during interviews with NGO fieldworkers and district government representatives. As the next section will demonstrate, this shift in habitus created scope for repatriados to draw upon their internal structures in new, more critical ways.

\subsection{Active agency and resiliency}

Following resettlement, many repatriado households reordered their agricultural projects across the different agri-ecological zones of the Lower Zambezi River valley. This process, in turn, produced a 
series of strategic orientations which promoted recovery from the 2007 flooding incident, as well as the potential mitigation of similar flooding events in the future. In Figure 3, these orientations have been arranged according to whether they resemble coping, coordinating, confounding or converting.

Figure 3: Strategic orientations of repatriado households in the case study resettlement villages

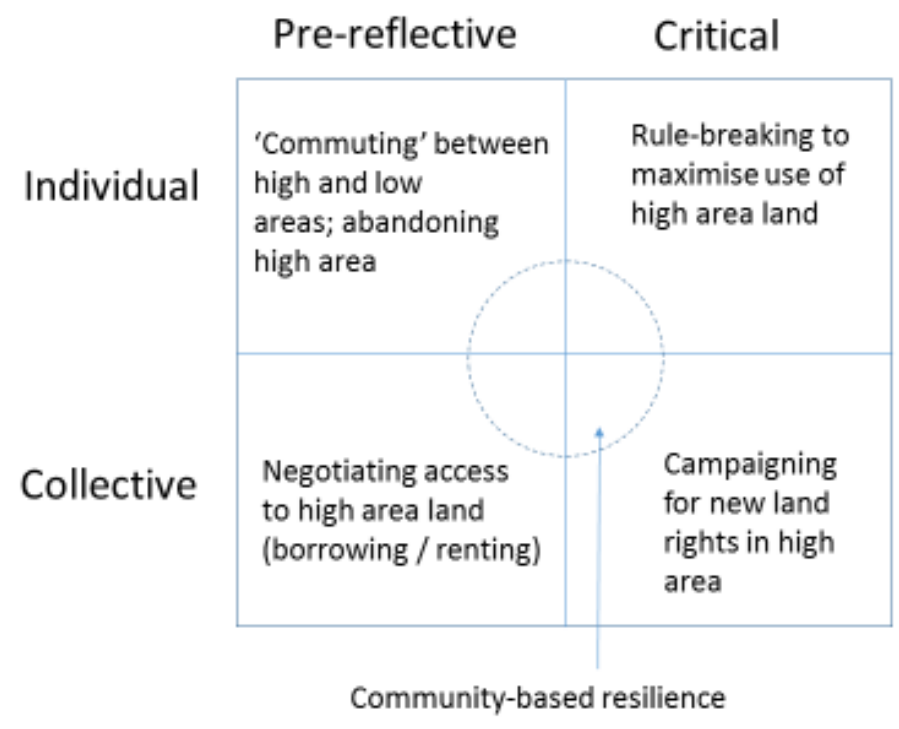

The remainder of this section presents a series of illustrations to show how these orientations work and how they came about.

\subsubsection{Pre-reflective strategies}

Actor activities in this category relate to repatriados whose reorganising activities following relocation to the high area largely reflected pre-existing structural configurations. 'Commuting' is an individual-based coping strategy in which repatriados base themselves in resettlement areas where their houses and possessions are free from floods but focus their activities on continuing to grow crops in the low area, as they used to do before relocation took place. They manage this by travelling to and from the river valley on a daily basis, although some farmers construct small, temporary shelters in the low area which enable them to remain close to their fields for a few days at a time.

Many commuters stated during interviews that they felt drawn to working in the river valley due to their familiarity with, and preference for, the farming environment, particularly the fertile soils. However, they reported a number of disadvantages of adopting this lifestyle. Commuters had to cover relatively large distances between their homes and fields, which could be several kilometres 
apart. This meant that, on arrival at their plots, they often had less time for agricultural production, and the long walk diminished their physical strength which they required to work the heavy clay soils. In addition, their crops were still vulnerable to the effects of flooding during the rainy season. As a result, many commuters were restricted to producing maize for subsistence consumption. Those repatriados who were unable or unwilling to secure a living in this manner abandoned the high area in order to return to the low area where they faced withdrawal of government-provided services.

Like commuters, farmers identified as 'negotiators' also resided in resettlement areas and focussed their agricultural activities in the low area. However, negotiators were able to draw on social connections, in most cases family and friends already resident in the high area, to borrow or rent lands outside of the floodplain. Respondents described during interviews how some people had been able to access up to two hectares in this way. However, negotiators also explained that they were limited by the poor financial terms through which they borrowed or rented land. In an attempt to overcome these shortcomings, negotiators often divided responsibilities between household members, with the female head continuing to commute to the low area to provide food for homebased consumption and the male head focussing on production of cash crops, such as sesame, in the high area.

These strategic orientations produce a number of different resiliency outcomes. Commuters and abandoners are essentially attempting to recover the same agricultural project activities that they had previous to 2007, even though this means ongoing exposure to floods. In contrast, coordinators are trying to mitigate the impacts of potential future floods on their agricultural activities. They do this by reprioritising their agricultural project activities, giving greater prominence to those that occur in the high area compared to the floodplain.

This mitigation outcome is demonstrated in the case of a repatriado small scale farmer, Mr JF of Inaçia village, who, following resettlement, decided to stop planting maize in the floodplain during the first growing season, switching this activity with high area-based production of sesame. He did this by renting one hectare of land through a personal contact who worked in the district administrator's office. During his interview, Mr JF reflected that he preferred this arrangement as he could now safely produce crops during both growing seasons. However, the financial terms of his arrangement were poor, meaning that the profits generated by his new venture were low. Mr JF stated: 
"The owner knew that I needed the land so could ask for a high rental price. What other option did I have? Maybe I could ask for high area land to be given to me. But I was too late in getting here [during the resettlement programme] and now the chance is gone...I am just a poor farmer and some people can take advantage".

As this quotation illustrates, coordination-based activities lead to mitigation of flooding impacts through alteration of repatriados' physical environments, rather than their social ones. Repatriados tended to adjust themselves within established patterns of social interaction as their circumstances changed through resettlement rather than exerting the transformative capacity, or power, necessary to challenge wider patterns of meaning, behaviour or resource control. As a result, the external structural conditions of unequal access to land which caused the emergence of the flooding problem in the first place are perpetuated in this case.

\subsubsection{Critical strategies}

In contrast to the pre-reflective orientations identified above, critical strategies are those in which actors exert power to challenge the regularised flows of social interaction which form the structural context of action. 'Rule-breaking' was pursued by middle farmer repatriados who, following relocation to the high area, started to utilise nearby agriculturally-productive land that had been acquired by external land investors but was currently sitting 'idle'. Officially, accessing high area land in this manner was illegal, a fact which had been relayed from the district administrator's office to resettlement villages by regulos during a series of recent village-based meetings. However, the middle-farmers ignored this decree, eventually transferring the majority of their agricultural activities to the high area where they would be free from the effects of floods. Like negotiators, therefore, rule-breakers began to practice high area-based farming during the first growing season. However, rule-breakers gained more profit as the financial terms of their land access was greatly improved compared to negotiators.

Rule-breakers largely acted on an individual basis to gain benefit from high area land. In contrast, 'campaigners' adopted a collective approach by pressing for improved land rights in the high area. For example, one group of repatriado widows explained how they had formed a pressure group to persuade the local regulo to allocate to them three plots of 'idle' land of two hectares each. The women described how they had taken it in turns to sit outside the regulo's house until he agreed to visit the district administrator on their behalf. As a result, the repatriado widows were able to 
produce maize and sesame in the high area during both growing seasons, having rented out their low area-based lands to other individuals.

As in the case of negotiators, both rule-breaking and campaigning lead to the mitigation of flooding impacts through a reorientation of project activities towards the high area. However, in doing so, rule-breakers and campaigner were able to enhance their resilience by exerting the power, or transformative capacity, necessary to alter their social environments, in addition to their physical ones. During interviews, middle farmers justified these actions through reference to the structures of domination in which they were positioned. To illustrate, 'Julio', who had illegally accessed two hectares of high area land and was now cultivating sesame, argued that:

"These rich people, they come from Maputo for the good land here, but who are they? Why don't they show their faces? If the land is not being used then we can make good use of it. Otherwise we will all keep suffering [as a result of the floods] and then in April we won't be able to harvest the sesame".

This quotation shows how the obscurity of the 'economic interests' that middle farmers were confronted with played into the hands of this group of repatriados as they acted contrary to the declarations of district-level authorities that land should not be utilised without the agreement of its owner. Similarly, discussions with the widow's group revealed how they were adjusting their behaviours to attempt to turn structural properties to their advantage. This is illustrated by the case of Mrs TD whose group began to make demands on the local regulo following their relocation to the high area. Mrs TD explained how this activity had been frowned upon at first by other village members, being viewed as socially disruptive. But her group persisted for three months until the regulo relented and went to see the district administrator on their behalf. Mrs TD justified this course of action in the following terms:

"The regulo has a lot more possessions than me, and received a large house and good land during resettlement. He even comes to meetings on a motorbike when I have nothing...But I suffered during the floods too many times. Why shouldn't I ask for land? Do the government really need it?"

As shown by this quotation, pre-existing structures of resource distribution meant that Mrs TD was initially in a disadvantaged position vis-à-vis ongoing flooding impacts in the low area. However, it 
also illustrates the manner in which she used the phenomenon of inequality to comprehend the disadvantages that she faced and came to define what she wanted to change about her situation.

Table 2 summarises the various outcomes of the strategic orientations identified in Figure 3 . These reflect the need to 'consolidate' a means of making a living in the high area whilst recovering from, and mitigating, the impacts of floods.

Table 2: Livelihoods and resilience outcomes for the resettled repatriado community

\begin{tabular}{|c|c|c|c|}
\hline \multirow[t]{2}{*}{ Strategy } & \multicolumn{3}{|l|}{ Outcomes } \\
\hline & $\begin{array}{l}\text { Agricultural } \\
\text { projects }\end{array}$ & Livelihoods & Resilience \\
\hline $\begin{array}{l}\text { Commute / } \\
\text { abandon } \\
\text { (cope) }\end{array}$ & No change. & $\begin{array}{l}\text { Mostly restricted to producing } \\
\text { maize for subsistence } \\
\text { consumption. }\end{array}$ & $\begin{array}{l}\text { Recovery of former agricultural } \\
\text { activities; crops still exposed to } \\
\text { impacts. }\end{array}$ \\
\hline $\begin{array}{l}\text { Negotiate } \\
\text { (coordinate) }\end{array}$ & $\begin{array}{l}\text { Relocation of first } \\
\text { cropping season to } \\
\text { high area. }\end{array}$ & $\begin{array}{l}\text { Splitting household duties } \\
\text { between subsistence crops in } \\
\text { low area and cash crops in high } \\
\text { area. }\end{array}$ & $\begin{array}{l}\text { Partial mitigation of impacts on } \\
\text { crops due to alteration of } \\
\text { physical environment. }\end{array}$ \\
\hline $\begin{array}{l}\text { Rule-break } \\
\text { (confound) }\end{array}$ & $\begin{array}{l}\text { Relocation of first } \\
\text { cropping season to } \\
\text { high area. }\end{array}$ & $\begin{array}{l}\text { Greater profits obtained from } \\
\text { cash cropping in high area. }\end{array}$ & $\begin{array}{l}\text { Partial mitigation of impacts on } \\
\text { crops due to alteration of } \\
\text { physical and social environments. }\end{array}$ \\
\hline $\begin{array}{l}\text { Campaign } \\
\text { (convert) }\end{array}$ & $\begin{array}{l}\text { Near complete } \\
\text { transfer of crops to } \\
\text { high area. }\end{array}$ & $\begin{array}{l}\text { Low area lands mostly rented } \\
\text { out or sold for profit. }\end{array}$ & $\begin{array}{l}\text { Near complete mitigation of } \\
\text { impacts on crops due to } \\
\text { alteration of physical and social } \\
\text { environments. }\end{array}$ \\
\hline
\end{tabular}

\section{Conclusion}

As stated at the outset of this article, there is increasing interest in the idea of building resilience as a means to help people undertake 'positive adaptation despite adversity' (Bottrell, 2009;323).

Resilience's theoretical and empirical appeal is reflected by the burgeoning mass of literature that has appeared on the subject in the past five years. However, concern has also been expressed that traditional interpretations of the concept can emphasise maintenance of the status quo. This makes the idea of resilience appear relatively conservative when juxtaposed with some of the more radical interventions needed to bring about meaningful change to poor and vulnerable people's lives.

How then can we develop a reframing of resilience that takes into account not only people's abilities to return to the status quo following the occurrence of a negative event, but also to act politically so as to challenge and alter the wider structural sources of their difficulties? This article set to address this question by considering actors' practices to recover from, and mitigate future sources of, negative events within the theoretical framework of the quadripartite cycle of structuration. It applied this framework to a case study of repatriado small-scale farmers following implementation 
of a flood-induced resettlement programme in Caia District, Mozambique. The analysis explored how repatriados' internal structures changed as a result of relocation from the floodplain to the high area, and how some repatriados drew on these structures in new ways as they attempted to reorganise their agricultural practices in the face of ongoing low area-based inundations.

The case study findings illustrate a number of instances in which actor priorities were frustrated by the wider structural context in which they operated. Many repatriados, for example, were confined to operating within established structural arrangements as their physical and social contexts changed, and therefore had to face the likelihood of floods damaging their crops on an ongoing basis. However, there were also examples of where structural properties played into the hands of initially worse off groups - such as widows and middle farmers - who, as a result, exerted the power, or transformative capacity, necessary to re-orientate their agricultural practices towards the high area, thus lessening the chances of future flooding re-affecting them. These insights are significant because they call into question the dominant notion in resilience theory that structures are external to agents, and that they act in direct opposition to actor practices to recover from, and mitigate, shocks and stresses. They suggest that structures are neither 'good' nor 'bad' per se, but rather particular configurations of facilitative and restrictive elements which actors must attempt to strategically negotiate following the occurrence of a negative event.

Reframing the role of social structures in this manner has implications for those who seek to build the resilience of vulnerable individuals and groups in society. Firstly, acknowledging the facilitative, as well as constraining, elements of the internal structures through which people act potentially illuminates a greater range of opportunities for promoting resiliency than would normally be the case, even in situations where agency is generating structural rigidity and making alteration of social systems difficult (Rodon et al., 2012). For example, in the case study, there was scope for NGOs to operate in the resettlement villages to lend support to repatriados' efforts to utilise 'idle' high area land following resettlement. However, most development organisations operating in Caia District overlooked these activities in favour of more 'standard' forms of livelihood support, such as cattle breeding projects. Insights such as these potentially allow development practitioners the opportunity to better align their interventions alongside the negotiations and day-to-day struggles already taking place in social contexts disrupted by the occurrence of shocks and stresses.

Secondly, viewing individuals and groups affected by negative events in the light of structuration theory helps avoid the temptation to assign blanket 'positive' or 'negative' status to different types 
of structure, thereby potentially pre-emptively writing off particular societal elements that might be important to resilience-building. Indeed, as stated by Masaki $(2006 ; 735)$, dominant groups can take on different identities depending on the particular context being faced at a particular time and therefore 'do not always seek to dominate others, but also tend to leniency toward the plight of marginal groups'. For example, in the case study, some of the regulos that were initially resistant to granting high area land to repatriados eventually relented and became the means through which this group of small-scale farmers could relocate their agricultural activities to higher areas of ground. Recognising from the outset the dual nature of structures creates greater room for manoeuvre in the search for common ground when seeking to resolve the conflicts over local resources that disruptive processes, such as floods, can cause.

In making these recommendations, it should be noted that the powers being exerted by individuals and groups in the case study settlements might, at first, seem rather modest in the sense that broader structures, such as the institutions shown in Figure 1, appear relatively untouched. However, there are a number of ways in which wider changes might come about. As pointed out by Bottrell $(2009 ; 334)$, "when adversity is identified as collective experience there is an important place for...advocacy. Conditions of adversity structured in inequalities, the distribution of resource and stigma warrant the practical expression of social justice orientations". In the Lower Zambezi River valley context, development organisations can build on the examples of individual and group-based resiliency highlighted in this article through advocacy work with government on dam management, resettlement and land tenure. Such a shift in emphasis is likely to be necessary if effective local resilience is to be achieved in the long-run.

These insights are especially pertinent to a global context in which national governments are increasingly looking to implement top-down resilience-building measures, such as resettlement, on vulnerable populations affected by climate-related shocks and stresses (Barnett and Webber, 2010). To some extent, the resettlement programme explored in this article provided the 'window of opportunity' (Birkmann et al., 2008) necessary to bring about the preconditions for social change. However, it also highlights the challenges involved in imposing large-scale relocation measures on people for two main reasons. First, the wider systems of social stratification in which the repatriado community was resettled, as well as the different strategic orientations that emerged out of this particular community following relocation, lend support to De Wet's (2006) argument that there is a need to pay more attention to social differentiation in resettlement programmes than has historically been the case. Second, the example of the difficulties faced by commuters in the case 
study reinforces the importance of the 'living with floods' concept in Mozambique. It suggests that, in addition to trying to guarantee complete safety through resettlement, resilience-building can also mean accepting the inevitability and uncertainty of flood impacts on exposed groups and developing strategies to cope with this reality through, for example, early warning systems (van Ogtrop et al., 2005). Without consideration of these issues, there is the risk that well-meaning interventions designed to build the resilience of local groups will simply help to recreate and perpetuate the constraining elements of structures in which vulnerable people are located.

\section{References}

Agrawal, A., Gibson, C. (1999) Enchantment and disenchantment: the role of community in natural resource conservation. World Development 27, 629-649.

Ainuddin, S., Routray, J.K. (2012) Community resilience framework for an earthquake prone area in Baluchistan. International Journal of Disaster Risk Reduction.

Alexander, J. (1997) The local state in post-war Mozambique: political practice and ideas about authority Africa: Journal of the International African Institute 67, 1-26.

Archer, M. (2000) Being human: The problem of agency. Cambridge University Press, Cambridge Arnall, A.H. (2014) A climate of control: flooding, displacement and planned resettlement in the Lower Zambezi River valley, Mozambique. Geographical Journal 180, 141-150.

Artur, L., Hilhorst, D. (2014) Floods, resettlement and land access in the lower Zambezi Valley, Mozambique Land Use Policy 36, 361-368.

Bailey, C., White, C., Plain, R. (1999) Evaluating qualitative research: dealing with the tension between 'science' and 'creativity'. Area 31, 169-183.

Barnett, J., Webber, M., (2010) Accommodating Migration to Promote Adaptation to Climate Change.

Bene, C., Newsham, A., Davies, M., Ulrichs, M., Godfrey-Wood, R. (2014) Review article: resilience, poverty and development. Journal of International Development 26, 598-623.

Bene, C., Wood, R.G., Newsham, A., Davies, M., (2012) Resilience: new utopia or new tyranny? Reflection about the potential and limits of the concept of resilience in relation to vulnerability reduction programmes. Institute of Developing Studies.

Birkmann, J., Buckle, P., Jaeger, J., Pelling, M., Setiado, N., Garschagen, M., Fernando, N., Kropp, J. (2008) Extreme events and disasters: a window of opportunity for change? Analysis of organizational, institutional and political changes, formal and informal responses after megadisasters. Natural Hazards 55, 637-655.

Bottrell, D. (2009) Understanding 'marginal' perspectives: towards a social theory of resilience. Qualitative Social Work 8, 321-229.

Boyd, C., Pereira, J., Zaremba, J., (2000) Sustainable livelihoods in southern Africa: institutions, governance and policy processes, SLSA Working Paper 2: Mozambique Country Paper. Institute of Development Studies, Brighton, pp. 1-36.

Brown, D.D., Kulig, J.D. (1996) The concept of resiliency: theoretical lessons from community research. Health and Canadian Society 4, 29-50.

Campbell, M.O. (2005) The ecological and social context of mammal hunting in the coastal savanna of Ghana. Geoforum 36, 667-680.

Cannon, T., Muller-Mahn, D. (2010) Vulnerabilty, resilience and development discourse in the context of climate change. Natural Hazards 55, 621-635.

Chambote, R., Boaventura, S.V., (2008) Reassentamento pela Metade no Vale do Zambezi. Oxfam Maputo.

Cleaver, F. (1999) Paradoxes of participation: questioning participatory approaches to development. Journal of International Development 11, 597-612. 
CMI, (2010) Gender and Poverty in Mozambique, CMI Brief. Chr. Michelsen Institute, Bergen, Norway.

Correa, E., (2011) Preventive Resettlement of Populations at Risk of Disaster: Experiences from Latin America. The World Bank, Washington, DC.

Coulthard, S. (2012) Can we be both resilient and well, and what choices do we have? Incorporating agency into the resilence debate from a fisheries perspective Ecology and Society 17, 4.

Craib, I., (1997) Back to utopia: Anthony Giddens and modern social theory, in: Bryant, C.G.A., Jary, D. (Eds.), Anthony Giddens: Critical Assessments. Routledge, London.

Crawford, G., Andreassen, B.A., (2013) Human rights, power and civic action: theoretical considerations, in: Andreassen, B.A., Crawford, G. (Eds.), Human rights, power and civic action. Routledge, London.

Cutter, S.L., Barnes, L., Berry, M., Burton, C., Evans, E., Tate, E., Webb, J. (2008) A place-based model for understanding community resilience. Global Environmental Change 18, 298-606.

Davidson, D.J. (2010) The Applicability of the Concept of Resilience to Social Systems: Some Sources of Optimism and Nagging Doubts Society and Natural Resources 23, 1135-1149.

Davoudi, S. (2012) Resilience: a bridging concept or a theoretical dead end? Planning Theory and Practice 13, 299-333.

De Wet, C., (2006) Policy Recommendations and Suggestions for Further Research, in: De Wet, C. (Ed.), Development-Induced Displacement: Problems, Policies and People. Berghahn Books, New York; Oxford.

DFID, (2011) Defining Disaster Resilience: A DFID Approach Paper. UK Department for International Development, London.

FEWS NET, (2011) Livelihoods Baseline Profiles: Limpopo Basin, Mozambique. US AID.

FFI, (2013) Wealth Ranking. Fauna and Flora International, London.

Fieldman, G. (2011) Neoliberalism, the production of vulnerability and the hobbled state: systematic barriers to adaptation Climate and Development 3, 159-174.

Folke, C. (2006) Resilience: the emergence of a perspective for social-ecological systems analyses Global Environmental Change 16, 253-267.

Gebauer, C., Doevenspeck, M. (2014) Adaptation to climate change and resettlement in Rwanda. Area 47, 97-104.

Giddens, A. (1979) Central problems in social theory: action, structure and contradiction in social analysis Macmillan, London.

Giddens, A. (1984) The constitution of society. Outline of the theory of structuration. Polity Press Cambridge.

Giddens, A., (1989) A reply to my critics, in: Heid, D., Thompson, J. (Eds.), Social theory of modern societies: Anthony Giddens and his critics. Cambridge University Press, Cambridge.

Grothmann, T., Patt, A. (2005) Adaptive capacity and human cognition: the process of individual adaptation to climate change. Global Environmental Change 2005, 199-213.

Hodgson, G.M. (2007) Institutions and individuals: interaction and evolution. Organization Studies 28.

Hulme, M. (2007) Geographical work at the boundaries of climate change. Transactions of the Institute of British Geographers 33, 5-11.

lanni, E. (2012) Land aquisitions and rural porvety: unveiling ambiguities in the District of Caia (Mozambique) Environment and Natural Resources Research 2, 52-61.

IISD, (2003) Increasing community resilience to climate related disasters through sustainable livelihoods. International Institute for Sustainable Development, Winnipeg, Canada.

IPCC, (2014) Summary for policymakers, in: Field, C.B., Barros, V.R., Dokken, D.J., Mach, K.J., Mastrandrea, M.D., Bilir, T.E., Chatterjee, M., Ebi, K.L., Estrada, Y.O., Genova, R.C., Girma, B., Kissel, E.S., Levy, A.N., MacCracken, S., Mastrandrea, P.R., White, L.L. (Eds.), Climate Change 2014: Impacts, Adaptation, and Vulnerability. Part A: Global and Sectoral Aspects. Contribution of 
Working Group II to the Fifth Assessment Report of the Intergovernmental Panel on Climate Change. Cambridge University Press, Cambridge, United Kingdom and New York, NY, USA.

Jayne, T.S., Mather, D., Mghenyi, E. (2010) Principle challenges confronting smallholder agriculture in sub-Saharan Africa. World Development 38, 1384-1398.

Jayne, T.S., Yamano, T., Weber, M.T., Tshirley, D., Rui, B.F., Chapoto, A., Zulu, B. (2003) Smallholder income and land distribution in Africa: implications for poverty reduction strategies. Food Policy $28,253-275$.

Koenig, D., (2005) Enhancing Local Development in Development-Induced Displacement and Resettlement Projects in: Wet, C.D. (Ed.), Development-Induced Displacement: Problems, Policies and People. Berghahn Books, Oxford

Kuruppu, N. (2009) Adapting water resources to climate change in Kiribati: the importance of cultural values and meanings. Environment Science and Policy 12, 799-809.

Kyed, H.M., Buur, L. (2006) New sites of citizenship: recognition of traditional authority and groupbased citizenship in Mozambique. Journal of Southern African Studies 32, 563-581.

Lebel, L., Manuta, J.B., Garden, P. (2011) Institutional traps and vulnerability to changes in climate and flood regimes in Thailand. Regional Environmental Change 11, 45-58.

Lister, R. (2004) Poverty. Polity, Cambridge.

Mansuri, G., Rao, V. (2004) Community-based and -driven development: a critical review The World Bank Research Observer 19, 1-39.

Masaki, K. (2006) The oppression/mancipation nexus in ongoing power struggles: village-power dynamics in western Nepal. Journal of Developing Areas 42, 721-738.

McDowell, C. (2013) Climate change adaptation and mitigation: implications for land acquisition and population relocation. Development Policy Review 31, 677-695.

Nielsen, J.O., Reenberg, A. (2010) Cultural barriers to climate change adaptation: a case study from northern Burkino Faso. Global Environmental Change 20, 142-152.

Norris, F.H., Stevens, S.P., Pfefferbaum, B., Wyche, K.F., Pfefferbaum, R.L. (2008) Community resilience as a metaphor, theory, set of capacities and strategy for disaster readiness. American Journal of Community Psychology 41, 127-150.

Oliveira, L., (2010) Baseline Study: Floodplan Management in the Zambezi Valley: Enhancing sustainable livelihood resilience. Save the Children, Maputo, Mozambique.

Patt, A., Schroter, D. (2008) Perceptions of climate risk in Mozambique: implications for the success of adaptation strategies. Global Environmental Change 18, 458-467.

Patterson, O., Weil, F., Patel, K. (2010) The role of community in disaster response: conceptual models. Population Research and Policy Review 29, 127-141.

Pelling, M., Manuel-Navarrete (2011) From resilience to transformation: the adaptive cycle in two Mexican urban centres. Ecology and Society 16.

Petz, D., (2015) Planned relocations in the context of natural disasters and climate change: a review of the literature The Brookings Institution, Washington D.C.

Popkea, J., Curtisa, S., Gamble, D.W. (2014) A social justice framing of climate change discourse and policy: Adaptation, resilience and vulnerability in a Jamaican agricultural landscape. Geoforum In press - corrected proof.

Pozzebon, M. (2004) The influence of a structurationist view on strategic management research. Journal of Management Studies 41, 247-272.

Pratt, B., Loizos, P. (1992) Choosing research methods: data collection for development workers. Oxfam, Oxford.

Punch, S. (2012) Hidden struggles of fieldwork: Exploring the role and use of field diaries. Emotion, Space and Society 5, 86-93.

Ribeiro, D., Dolores, S., (2011) River Basin Management in the Middle and Lower Zambezi in Critical Periods Justica Ambiental, Maputo.

Rodon, J., Maria, J.F., C, G. (2012) Managing cultural conflicts for effective humanitarian aid. International Journal of Production Economics 139, 366-376. 
Schoon, I. (2006) Risk and resilience: adaptations in changing times. Cambridge University Press, Cambridge.

Schwarz, A.M., Bene, C., Bennett, G., Boso, D., Hilly, Z., Paul, C., Posala, R., Sibiti, S., Andrew, N. (2011) Vulnerability and resilience of remote rural communities to shocks and global changes: empirical analysis from the Solomon Islands. Global Environmental Change 21, 1128-1140.

Scodanibbio, L., Manez, G. (2005) The World Commission on Dams: A fundamental step towards integrated water resources management and poverty reduction? A pilot case in the Lower Zambezi, Mozambique. Physics of the Chemistry and Earth 30, 976-983.

Stal, M. (2011) Flooding and relocation: the Zambezi River Valley in Mozambique. International Migration 49, 125-145.

Stones, R. (2005) Structuration theory. Palgrave Macmillan, Basingstoke.

Toulmin, C. (2008) Securing land and property rights in Sub-Saharan Africa: the Role of Local Institutions. Land Use Policy 26, 10-19.

Twigg, J., (2007) Characteristics of a Disaster-Resilient Community DFID Disaster Risk Reduction Interagency Coordination Group

UN HABITAT, (2012) Post-disaster housing damage assessment: Zambezia Province, Mozambique. UN HABITAT Maputo.

USAID, (2008) Mozambique Livelihood Baseline Profile. United States Agency for International Development, Washington DC.

van den Berg, J. (1987) A peasant form of production: wage-dependent agriculture in southern Mozambique Canadian Journal of African Studies 21, 375-389.

van Ogtrop, F.F., Hoekstra, A.Y., van der Meulen, F. (2005) Flood management in the lower Incomati river basin, Mozambique: two alternatives Journal of the American Water Resources Association 41, 607-619.

Walker, J., Cooper, M. (2011) Geneologies of resilience: from systems ecology to the political economy of crisis adaptation. Security Dialogue 42, 143-160.

Welsh, M. (2013) Resilience and responsibility: governing uncertainty in a complex world The Geographical Journal 180, 15-26.

West, H.G. (1998) 'This neighbour is not my uncle': changing relations of power and authority on the Mueda Plateau. Journal of Southern African Studies 24, 141-160.

West, H.G., Kloeck-Jenson, S. (1999) Betwixt and between: 'traditional authority' and democratic decentralisation in post-war Mozambique. African Affairs 98, 455-484.

West, H.G., Myers, G.W. (1996) A piece of land in a land of peace? State farm divesture in Mozambique. The Journal of Modern African Studies 34, 27-51.

Wilson, G. (2006) Beyond the technocrat? The professional expert in development practice. Development and Change 37, 501-523.

Wisner, B., Blaikie, P., Cannon, T., Davis, I. (2003) At risk: natural hazards, people's vulnerability and disasters, Second edition ed. Routledge, London. 